\title{
On Path and Measures of Ideal and Belief Education for College Students
}

\author{
Rui Wang \\ Student Development and Affairs Center of Bohai University, 121000 Jinzhou, Liaoning, China
}

Keywords: college students; ideal and belief; implementation path

\begin{abstract}
Contemporary college students are the new force and reserve force of socialist modernization construction of our country, shoulder great historical mission of the socialist cause of our country, and are the future and hope of China. Their ideal and belief are related to the building of a moderately prosperous society in an all-round way and the realization of the great rejuvenation of the Chinese nation. This paper, generally, from the current situation of college students' ideal and belief in the new era, explored implementation paths of their ideal and belief and puts forward viewpoints and opinions, so as to provide effective reference for strengthening the ideal and faith education of college students.
\end{abstract}

Xi Jinping takes the firm ideal and belief as the primary task of the ideological construction of the Chinese Communist Party in the reports of the 19th National Congress of the CPC, stresses that "Marxism shall be upheld, the lofty ideal of communism and the common ideal of socialism with Chinese characteristics shall be firmly established, and socialism core value shall be cultivated and practiced". This year is the opening year of the spirit of the 19th National Congress of the CPC. Contemporary college students are the hope of the motherland and the nation, and the key force for the social development. Their ideal and belief, political ideas and concepts are directly related to the cause of the CPC, the construction of socialism, and the future of the Chinese nation. Ideal and belief is the strong spiritual support and driving force for uniting and pioneering, and beacons and guiding lights for the healthy growth of college students. The emphasis on college students' ideal and belief education from the nation is evident, and the main purpose is to uphold socialist beliefs. However, how to effectively improve the ideal and belief of college students is the key point.

\section{The important significance of ideal and belief education of college students}

The strengthening of ideal and belief education of college students are of important significance from the perspective of society and college student themselves. The ideal and belief education of college students are related to higher education and the growth of college students, and the construction of state and the progress of society. Ideal and belief is ideological source of their own impetus. The pursuit of longing goal is the spiritual backup force and ideal backbone of our political stand and the world view, view of life and value in life. Ideal and belief education is conducive to the exploration of the regularity of ideal and belief education in the new era, which is the core content of ideological and political education in colleges and universities. Therefore, we must cultivate qualified personnel for social development, and combine concept of talents and concept education to deepen into our ideology. This kind of education is very important, which can enable college students to understand the world and understand their position in the world, can enable certain individuals to complete and realize his socialization process, so as to truly become a member of a particular society and be accepted by society, and can enable individuals to understand their own obligations and responsibilities and feel the significance and value of survival.

\section{The breakthrough point of ideal and belief education of college students}

\subsection{To conduct ideal and belief education of college students from breakthrough point}

The slightest deviation in the ideal and belief education can easily make it become an armchair strategist, so the ideal and faith education for college students must be aimed at enabling students to 
achieve key changes in life development and learning methods as soon as possible, enhancing their sense of historical mission and responsibility, and firmly grasping concrete thoughts of students, strengthening the education of ideal and belief from the enrollment, establishing the correct goal of struggle and identify breakthrough point, and cultivate youths in new era with independent healthy personality to form scientific view of world, view of life and value. At this critical turning point and node in life, it is necessary to implement the combination of guiding individual ideal and social ideal and specialize the education of ideal and belief, in this way, the patriotic concept can be implemented in the action. To establish the common ideal of building socialism with Chinese characteristics, to take ideal and belief as the core of ideological and political education for college students, and to combine the orientation and characteristics of higher education, training modes and methods. The implementation will effectively improve the overall quality of college students, and at this stage, their own thinking model, moral standards and value system should be gradually established.

\subsection{To help college students to switch roles from the practice}

Since ideological and political education involves a wide range of aspects, educators must implement abstract education in practice, based on education of ideal and belief, and conduct the patriotic education for their growth. Ideal and belief education can enable college students to adapt to college life as soon as possible, cultivate the patriotism of college students, and effectively help freshmen complete the transition from students to social men. Modern college students have a strong sense of self-superiority, such as "self-advocating", excessive self-assertion, lack of collective consciousness and etc. For unsophisticated college students, their choice and recognition are not comprehensive enough, and they will inevitably be impacted and influenced by decadent ideology and culture. Contemporary college students are easy to accept new things, while the money worship and individualism in Western society are all focused on the self-ideals and interests, thus, when they encounter the choice of ideal and belief, effective education cannot be separated from the reality. On the other hand, it is necessary to fully recognize the urgency of ideal and belief education. All education is conducted in a certain era. Ideal and belief education is an important and indispensable part of their spiritual world. If we can start from the era and group characteristics and focus on the ideal and belief education of college students, which will positively guide the three view of students and firmly grasp the correct direction.

\section{The implementation path of ideal and belief education for college students}

\subsection{To make use of orientation education for freshman and strengthen ideal and belief education for college students}

Based on ideal and belief education, patriotism education shall be conducted, and organize freshman to visit university history museum, at the critical turning point and node of life, on the premise of respecting student's individual differences and diversified needs, which also meets validity and acceptable requirements. While cultivating its positive and healthy psychological state and improving the ability of psychological adjustment, it is an important support for ideal and belief education, and patriotic films are provided to enhance the ability of psychological adjustment. The forms of education adopted are vivid and diverse, which virtually expand the coverage, mass media, such as newspapers, publications, radio stations, television stations, and the Internet, are popularized to deepen teaching concepts, reform teaching methods, improve teaching methods, and improve teaching quality, combined with growth and development of individuals, passive acceptance must be transformed to active absorption. Patriotism shall be promoted. Patriotism education is the most easily acceptable emotional education; finally, patriotism education comes out like a mathematics quiz, remembered in mind, revealed in true feelings, and the desire for ideal and belief is naturally expressed from the heart. 


\subsection{To implement the grown-up plan and internalize the requirement of ideal and belief}

The education of ideal and belief should start from the actual life of college students. First of all, in accordance with teaching requirements and plans, curriculum construction, teacher team construction and teaching material construction shall be comprehensively strengthened, and habits and inertia should be formed in patriotic identity training. At the same time, teacher must give top priority to ideal and belief in class, serve as a model for others, and take ideal and belief education as the basis, and make use of university history of growth to inspire patriotic enthusiasm and foster national pride. Secondly, the purity of the teaching staff is an important part of the education of ideal and belief cultivation for college students. Students should keep in mind their ideal and belief in cultivating their positive and healthy psychological state and enhancing the ability of psychological adjustment. For instance, the use of multimedia and other educational means to enrich the classroom content. In addition to the theoretical knowledge of ideology and politics, the reality should also be combined for thanksgiving education, honest education, responsibility education for students to strengthen the ideal and belief of socialism; thirdly, establish correct three views, strengthen the education of ideal and belief, and deepen to the ideological consciousness. To establish correct goals, we must carry out innovative ideological and political education activities, guide college students to integrate personal ideal with social ideal, cultivate qualified personnel for social development, combine the concept of talents and concept education, and guide students to take the initiative instead of accepting it passively.

\subsection{To innovate educational methods and content and strengthen the effectiveness of ideal and belief education for college students.}

With the wide application of new technologies and new means in information dissemination, the main participant of ideal and belief education in colleges and universities is teachers. The quality of teachers directly affects the effectiveness of college students' ideal and belief education. Campus public opinion shall be guided, educational methods shall be innovated, and the media of cultural dissemination is advanced. College students today are active and lively, and they don't like learning. A variety of activities can be organized to enhance the understanding of the importance of ideal and belief. Students can learn the power of ideal and belief from a variety of amateur cultural activities, so as to correctly establish correct values, follow the examples, and ideal and belief will become the power force for life struggle, also a beacon on the road of struggle. The education of ideal and belief must permeate every level of life, in small and subtle things, from the people and things around them, and students are required to remember the mission on the road of study, not forget the promises and goals promised, to experience the sense of accomplishment and responsibility in fulfilling their mission. On one hand, to effectively improve ideal and belief education. Various forms of media are used to broadcast patriotic propaganda films, to promote the model of patriotic figures, to set an example and to create a new atmosphere, which is important for the psychological transition of students. Gradually guide personal ideal and belief to social ideal and belief. It is imperative to demonstrate the ideal and belief of socialism and improve the overall quality of the teaching staff and create a good campus atmosphere. The education forms used are vivid and diverse, which virtually expand the coverage, mass media such as newspapers, publications, radio stations, television stations, and networks are popularized basically. For example, school newspapers, school radio stations, blackboard newspapers, and campus networks are used to help contemporary college students establish healthy ideal and belief.

\section{Conclusion}

We must combine the ideological realities of contemporary college students and start from the source of the education of ideal and belief to every detail of life, and carry out innovative ideological and political education activities. The report of the 19th National Congress of the CPC stated that "Youth prospers and strengthens a nation. The younger generation has ideals, skills, and responsibility, the country will have a bright future and the nation will have hope". Young students 
are required to internalize the spirit of the 19th National Congress of the CPC in mind, externalize it in actions, strengthen their ideal and belief, and work down-to-earth so as to fly their youthful dreams in realizing the vivid practice of Chinese dream, and write their life in their unremitting struggle for the interests of the people.

\section{References}

[1] Ren Zhongjie. On Effectiveness of Ideal and Belief Education for Contemporary College Students [J]. Education for Chinese After-school, 2011(4), 6.

[2] Li Hui. Ideal and Belief in the Teaching of "Ideological and Moral Cultivation and Basic Law" [J]. Journal of Ideological \& Theoretical Education, 2008(3), 40.

[3] Liu Huixin, Wang Zhihong, Zhang Lifu. Research on the Path Selection of University Students' Ideological and Political Education [J]. Journal of Chongqing Education College, 2011(3), 148. 